\title{
Acculturation is associated with older Turkish immigrants' self-management abilities
}

\author{
Jane M. Cramm* and Anna P. Nieboer
}

\begin{abstract}
Background: The few previous studies investigating acculturation and self-management have suggested that increased participation in (or adaptation to) the host culture is associated with better health and disease management. However, research on the relationship between acculturation strategies (attachment to the Dutch and Turkish cultures) and broader self-management abilities among older Turkish immigrants in the Netherlands is lacking. This study aimed to investigate this relationship in this population.

Methods: Turkish immigrants aged $>65$ years and residing in Rotterdam, the Netherlands $(n=2350)$, were identified using the municipal register. In total, 680 respondents completed the questionnaire (32\% response rate).

Results: The average age of the respondents was 72.90 (standard deviation, 5.02; range, 66-95) years and 47.6\% of respondents were women. The majority (80.3\%) of respondents reported having low educational levels. Women, single individuals, less-educated respondents, and those with multimorbidity experienced lower levels of attachment to the Dutch culture and reported poorer self-management abilities. Slightly stronger relationships were found between selfmanagement and attachment to the Dutch culture than attachment to the Turkish culture. Multimorbidity negatively affected the self-management abilities of older Turkish people living in the Netherlands.

Conclusions: The study findings indicate that especially attachment to the Dutch culture matters for the self-management abilities of older Turkish immigrants in the Netherlands. Given the high prevalence of multimorbidity in this population, investment in their self-management abilities is expected to be beneficial. Special attention is needed for women, single individuals, less-educated people, and those with multimorbidity. Interventions aiming to better integrate these groups into Dutch society are also expected to be beneficial for their self-management abilities.
\end{abstract}

Keywords: Acculturation, Immigrants, Self-management, Ageing, Integration

\section{Background}

Health care systems worldwide are overwhelmed in dealing with the consequences of ageing populations, and the effects of preventive care remain limited $[1,2]$. In the Netherlands, the proportion of older Turkish immigrants is increasing much more rapidly than that of older Dutch natives [3]. Furthermore, the prevalences of chronic diseases [4], poor health [5], depression [6], and health care utilisation [7] are greater among Turkish people than among natives in the Netherlands, making older Turkish

\footnotetext{
* Correspondence: cramm@eshpm.eur.nl

Department of Social Medical Sciences, Erasmus School of Health Policy and Management, Erasmus University Rotterdam, P.O. Box 1738, 3000 Rotterdam,
} $\mathrm{DR}$, The Netherlands

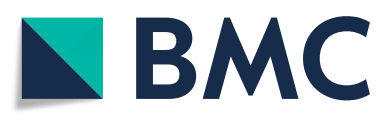

(c) The Author(s). 2019 Open Access This article is distributed under the terms of the Creative Commons Attribution 4.0 International License (http://creativecommons.org/licenses/by/4.0/), which permits unrestricted use, distribution, and reproduction in any medium, provided you give appropriate credit to the original author(s) and the source, provide a link to the Creative Commons license, and indicate if changes were made. The Creative Commons Public Domain Dedication waiver (http://creativecommons.org/publicdomain/zero/1.0/) applies to the data made available in this article, unless otherwise stated. ture emerges in the rest of Europe; chronic diseases, depressive symptoms, functional limitations, and health care use are much more prevalent among immigrant populations than among natives $[8,9]$. The rapid increase in the prevalence of chronic diseases among older (immigrant) populations is an important factor underlying the increased demand for health care services and constraints on the organisation and delivery of care in Europe $[9,10]$. Increasing self-management abilities to prevent or reduce early functional loss could partially relieve this burden on the health care system by allowing Turkish immigrants to better maintain independent and autonomous lifestyles for longer periods of time [11]. 
Investing in older people's self-management abilities is expected to help prevent further declines in functioning and well-being [12, 13]. Most such efforts target the physical health aspects of ageing and dealing with chronic diseases (e.g. treatment adherence, physical exercise, and healthy diet); the latest evidence, however, shows that care and support should also target broader self-management abilities to maintain overall well-being, such as initiative taking, investment behaviour (e.g. maintaining contact with loved ones, pursuing interests, and keeping busy), and self-efficacy (e.g. belief in one's ability to achieve goals and express care for others) [14, 15]. Our recent study showed the importance of these broader self-management abilities in addition to health behaviours for physical health, depressive symptoms, and well-being among Turkish older immigrants in the Netherlands, especially among chronically ill individuals [16]. Given the vulnerability of older Turkish people in the Netherlands, enhancement of this group's broader self-management abilities is expected to help them deal with the ageing process. Such efforts require an increased understanding of factors that influence self-management abilities; who are good self-managers and who are not? How can we improve individuals' self-management abilities? The degree to which older Turkish people adopt new practices, such as self-management abilities, in their personal behavioural repertoires may vary substantially depending on the level of integration in the new cultural environment. Currently, however, we lack research on this issue.

One aspect that deserves closer examination is acculturation [17-21]. Acculturation has been associated with significant changes in self-management (e.g. achievement of self-efficacy), healthier behaviours, and overall health among immigrants [17, 22-25]. Rather than being conceptualised as a process by which people lose connections to their original culture [26], acculturation should be conceived in terms of individuals' negotiation of two cultural entities [27, 28]. Responding to distinct sets of norms from the original and host cultures, acculturating individuals develop their own interpretations of appropriate values, customs, and practices as they negotiate between cultural contexts [29]. People have greatly variable abilities to function in new cultural environments [30], and they may seek different levels of attachment to and involvement in a host culture and their culture(s) of origin [31]. Therefore, acculturation is usually defined along two dimensions, expressing the degree of contact and participation in the larger 'new' society and the maintenance of the 'old' heritage culture and identity [32-34]. Individuals may adapt to a new environment without giving up their adherence to the culture of origin [35-39]. The assumption that acculturation is a bidimensional process has been tested in a few studies, and the results have supported the bidimensional model $[40,41]$. Four acculturation strategies have been identified $[34,42]$.

\section{Four acculturation strategies}

If the situation occurs that older immigrants do not wish to maintain their cultural identity and rather seek daily interaction with the host culture, they are following the assimilation strategy [43]. If the opposite occurs and older immigrants rather maintain their cultural identity and avoid any interaction with the host culture, they are following the separation strategy. Older immigrants who are interested in both cultures use the integration strategy in which they maintain their original culture while at the same time engage in daily interactions with the host culture. Integration may take various forms and degrees of integration, including alternation between and merging of cultural ways [42]. Finally, the marginalisation strategy refers to situations in which older immigrants have lost the ability and interest to connect with their original culture as well as the host culture. The assessment of these acculturation strategies is a core feature of acculturation research (e.g. [39, 43, 44-46]), and variations in these strategies have been related to variations in acculturation experience and to adaptation (e.g. [47]).

One could reason that those following the integration strategy of acculturation are better self-managers because they retain valued heritage-culture features while selectively and skilfully adopting new cultural behaviours and beliefs facilitating adjustment. In other words, the skills required to adjust to and integrate into the host culture while holding on to the heritage culture are also beneficial in terms of the ability to take initiative and to invest using a long-term perspective (broader self-management abilities). Similarly, biculturalism or bicultural competence involves the appropriate application of dual modes of social behaviour (e.g. communication skills) to enhance self-determination and adjustment in different cultural contexts $[47,48]$. Furthermore, integration, biculturalism, and bicultural competence are associated with the alternation model of second culture acquisition, in which positive bicultural adjustment results from the alteration of behaviours for different contexts, formation of meaningful bicultural relationships, and valuing and understanding of both cultures $[30,49,50]$, which facilitate the expression of care for others and investment in social relationships. Those who successfully apply dual modes of social behaviour and develop attachment to the host culture, as well as the culture of origin, are therefore also expected to be better self-managers [51, 52]. Those who follow the assimilation strategy also successfully adopt new cultural behaviours and beliefs, which is expected to be beneficial to their self-management abilities; 
those who more successfully adjust to a different cultural context are expected to have a stronger belief in their ability to achieve certain goals in life and to adopt a more positive attitude. Hence, they are more likely to report stronger self-efficacy skills and hold a more positive frame of mind.

The few studies investigating acculturation and selfmanagement $[51,52]$ have suggested that increased participation in (or adaptation to) the host culture (i.e. integration and assimilation) is associated with better health and disease management compared with adoption of the marginalisation and separation acculturation strategies. However, research on the relationship between acculturation strategies (attachment to the Dutch as well as the Turkish culture) and broader self-management abilities among older Turkish immigrants residing in the Netherlands is lacking. This study thus aimed to investigate this relationship in this population, and to examine differences in acculturation strategies and self-management between sub-groups of older Turkish immigrants (men and women, those with high and low education levels, those living alone and those who are married, and those with and without multimorbidity).

\section{Methods}

\section{Data collection}

For this cross-sectional study community-dwelling older Turkish people (aged $\geq 65$ years) residing in Rotterdam, the Netherlands, were identified using the municipal register $(n=2350)$. Respondents were asked to fill in a questionnaire provided in Dutch and Turkish in 2015 and the first 2 months of 2016. Questionnaire were first sent via post and non-respondents received a postal reminder. After these attempts via mail we used at least two house visits to reach our respondents (interviewers both Dutch and Turkish). A total of 213 were ineligible due to change of address $(n=110)$, serious medical issue or death $(n=102)$, and non-Turkish ethnic background $(n=1)$. Of the 2137 eligible respondents a total of 680 filled in the questionnaire leading to a $32 \%$ response rate.

\section{Ethical approval}

According to the rules laid down in the Dutch law and followed by the Central Committee on Research Involving Human Subjects (CCMO), the current study did not fall within the scope of the Medical Research Involving Human Subjects Act and therefore did not require prior review by an accredited medical research and ethics committee or the CCMO. All participating respondents were informed about the study and they were assured that participation was completely anonymous and voluntary prior to providing consent.

\section{Measures}

Professional native Turkish translators living in the Netherlands translated the questionnaire (which contained items from multiple instruments and those eliciting background characteristics) into Turkish. All of the translators were official and certified, and studied Turkology, ensuring high-quality translation. The procedure was as follows: a first translator translated the Dutch instrument into Turkish. A second translator then checked all aspects of the initial translation (e.g. spelling, grammar, terminology, and cultural interpretation of words). A third translator then performed back translation to ensure that the items had been translated properly. Finally, the questionnaire was tested among older native Turkish people to ensure content validity for the target population. The Turkish versions of the included measures are presented in the appendix.

The Psychological Acculturation Scale [53, 54] was used to assess attachment to the Dutch and Turkish cultures. This scale was originally developed to assess individuals' sense of emotional attachment to, belonging within, and understanding of the Anglo American and Latino-Hispanic cultures [53], and was later used to measure psychological acculturation among Moroccan people in the Netherlands. The Dutch-Moroccan psychological acculturation subscale showed a good fit to the data in both populations. Overall, this adapted instrument demonstrated strong psychometric properties in previous studies $[53,54]$. In the current study, the Dutch and Turkish Psychological Acculturation Subscales (D-PAS and T-PAS, respectively) showed good reliability (Cronbach's alpha, 0.83 and 0.86 , respectively). In addition to using the D-PAS and T-PAS to investigate attachment to the home and host cultures, in line with previous research [55-57], we constructed the four acculturation strategies by subjecting the home and host culture scales to a median split [36, 58-60]. After calculating the median score on the home (T-PAS) and host culture (D-PAS) of the entire population we now know the acculturation strategy of each individual;

- T-PAS and D-PAS of an individual both above the median of the total population represents the integration strategy

- T-PAS below the median and D-PAS above the median represents the assimilation strategy

- T-PAS above the median and D-PAS below the median represents separation the strategy

- T-PAS and D-PAS both above the median represents the marginalization strategy

Self-management abilities were assessed using an adjusted version of the short (18-item) version of the SelfManagement Ability Scale (SMAS-S) [61]. The SMAS-S 
assesses the following six self-management abilities: (1) the ability to take initiative, (2) the ability to invest in those resources that create long-term benefits, (3) the ability to ensuring multifunctionality of resources (gaining and maintaining resources or activities that serve multiple gains), (4) the ability to maintain a variety in resources (gaining and maintaining various resources), (5) the ability to maintain a positive frame of mind, and (6) self-efficacy (the ability to gain and maintain a belief in personal competence to achieve well-being). While the original instrument contains six answering categories we reduced the number of response categories for five subscales from six to four to make completion of the instrument less complex. A higher score implies better selfmanagement abilities. The item 'when things go against you, how often do you think that it could always be worse?' proved to be problematic during validation which is why we removed this item from the Turkish version of the instrument. The SMAS-S proved to be a reliable instrument as the Cronbach's alpha based on the six subscales was 0.92 .

Concerning background characteristics, respondents were asked to report the highest educational level completed in the Netherlands or abroad, with the option to select 'no schooling' or to write in another response for unlisted forms of schooling. This variable was dichotomised as low (completion of elementary school or less) and high (more than elementary school). Respondents were also asked about their marital status (married, divorced, widowed, single, or cohabitating). This variable was dichotomised as divorced, single, or widowed and married. Finally, we asked respondents to report their age, gender, and number of chronic conditions experienced in the past 12 months.

\section{Analyses}

The characteristics of the study sample were examined using descriptive statistics. Differences in acculturation and self-management abilities between sub-groups (men and women, those with high and low educational levels, those living alone and those who were married, and those with and without multimorbidity) were tested using independent-samples $t$ tests and chi-squared tests. Bivariate associations of variables expressing background characteristics, acculturation, and self-management abilities were examined. Regression analyses were then performed to identify relationships among background characteristics, acculturation, and self-management abilities among older Turkish immigrants in Rotterdam, the Netherlands.

\section{Results}

About half (47.6\%) of the respondents were women. The average age of respondents was 72.90 [standard deviation (SD), 5.02; range, 66-95] years (Table 1). Most $(80.3 \%)$ respondents had low educational levels, and $69.4 \%$ had multimorbidity. About one-third (34.1\%) of respondents used the integration acculturation strategy, $24.7 \%$ used the separation strategy, $23.0 \%$ used the marginalisation strategy, and $18.2 \%$ used the assimilation strategy.

Tables 2 and 3 show differences in self-management, acculturation strategies, and attachment to the Dutch and Turkish cultures across sub-groups of older Turkish immigrants. Compared with men, women used the separation strategy more often $(33.6 \%$ vs. $16.7 \% ; p<0.001)$ and the integration $(29.3 \%$ vs. $38.5 \% ; p=0.015)$ and assimilation $(13.5 \%$ vs. $22.4 \% ; p=0.004)$ strategies less often. No difference in the use of the marginalisation strategy was found between men and women. Compared with those with higher education levels, less-educated respondents used the separation strategy more often $(28.4 \%$ vs. $10.7 \% ; p<0.001)$ and the integration strategy less often $(31.0 \%$ vs. $45.8 \% ; p=0.002)$. Compared with married individuals, single respondents used the separation strategy more often $(31.7 \%$ vs. $22.1 \% ; p=0.015)$ and the integration strategy less often $(25.1 \%$ vs. $37.8 \%$; $p=0.002)$. Compared with respondents with multimorbidity, those without multimorbidity used the integration strategy more often ( $40.5 \%$ vs. $31.4 \%, p=0.002$; Table 2$)$.

Women were poorer self-managers than men [2.45 (SD 0.64) vs. 2.57 (SD 0.61); $p=0.017]$, more-educated respondents were better self-managers than those with less education [2.64 (SD 0.59) vs. 2.48 (SD 0.63); $p=0.011]$, married people had significantly higher SMAS-S scores than did single individuals [2.55 (SD 0.61 ) vs. 2.43 (SD 0.65); $p=0.030$ ], and those with multimorbidity were poorer self-managers than those without

Table 1 Descriptive statistics for older Turkish immigrants ( $n=$ 680)

\begin{tabular}{lll}
\hline Characteristic & Range & $\%$ or mean (SD) \\
\hline Sex (female) & & $47.6 \%$ \\
Age (years) & $66-95$ & $72.90(5.02)$ \\
Marital status (single/widowed) & & $28.7 \%$ \\
Education (low) & & $80.3 \%$ \\
Number of chronic diseases & $0-10$ & $2.68(1.87)$ \\
Co-/multi-morbidity & & $69.4 \%$ \\
Self-management abilities & $1-4$ & $2.52(0.62)$ \\
Attachment to the Turkish culture & $1-5$ & $3.92(0.69)$ \\
Attachment to the Dutch culture & $1-5$ & $3.19(0.77)$ \\
Integration acculturation strategy & & $34.1 \%$ \\
Assimilation acculturation strategy & & $18.2 \%$ \\
Separation acculturation strategy & & $24.7 \%$ \\
Marginalisation acculturation strategy & & $23.0 \%$
\end{tabular}

SD standard deviation 
Table 2 Differences in acculturation strategies between older Turkish sub-groups ( $n=680$ )

\begin{tabular}{|c|c|c|c|c|c|c|c|c|c|c|c|c|}
\hline \multirow[b]{2}{*}{ Acculturation strategy } & \multicolumn{3}{|c|}{ Gender (\%) } & \multicolumn{3}{|c|}{ Educational level (\%) } & \multicolumn{3}{|c|}{ Marital status (\%) } & \multicolumn{3}{|c|}{ Multimorbidity (\%) } \\
\hline & Male & Female & $x^{2}$ & High & Low & $x^{2}$ & Single & Married & $x^{2}$ & No & Yes & $x^{2}$ \\
\hline Integration & $38.5 \%$ & $29.3 \%$ & 0.015 & $45.8 \%$ & $31.0 \%$ & 0.002 & $25.1 \%$ & $37.8 \%$ & 0.002 & $40.5 \%$ & $31.4 \%$ & 0.027 \\
\hline Assimilation & $22.4 \%$ & $13.5 \%$ & 0.004 & $22.9 \%$ & $17.0 \%$ & 0.127 & $16.4 \%$ & $18.6 \%$ & 0.569 & $19.5 \%$ & $17.6 \%$ & 0.576 \\
\hline Separation & $16.7 \%$ & $33.6 \%$ & $<0.001$ & $10.7 \%$ & $28.4 \%$ & $<0.000$ & $31.7 \%$ & $22.1 \%$ & 0.015 & $21.1 \%$ & $26.3 \%$ & 0.192 \\
\hline Marginalisation & $22.4 \%$ & $23.7 \%$ & 0.708 & $20.6 \%$ & $23.7 \%$ & 0.487 & $26.8 \%$ & $21.5 \%$ & 0.176 & $18.9 \%$ & $24.7 \%$ & 0.123 \\
\hline
\end{tabular}

Results are based on two-sided tests

multiple chronic diseases [2.42 (SD 0.62) vs. 2.74 (SD $0.59) ; p<0.001$; Table 3]. The same patterns were found for attachment to the Dutch culture, with significantly higher scores among men, more-educated respondents, married individuals, and respondents without multimorbidity.

The results of the bivariate correlation analyses are shown in Table 4. A positive relationship was found between older age and attachment to the Turkish culture $(r=0.08, p<0.05)$. In accordance with the differences found between groups, attachment to the Dutch culture was related negatively to female gender $(r=-0.20, p<$ $0.001)$, single status $(r=-0.15, p<0.001)$, low educational level $(r=-0.20, p<0.001)$, and multimorbidity $(r=-0.15, p<0.001)$. A weak positive relationship was found between attachment to the Turkish culture and attachment to the Dutch culture $(r=0.09, p<0.05)$. Selfmanagement was related negatively to female gender $(r=-0.10, p<0.05)$, older age $(r=-0.10, p<0.01)$, single status $(r=-0.09, p<0.05)$, low educational level $(r=$ $-0.10, p<0.01)$, and multimorbidity $(r=-0.32, p<$ 0.001 ). Positive relationships were found between selfmanagement and attachment to the Turkish $(r=0.16$, $p<0.001)$ and Dutch $(r=0.26, p<0.001)$ cultures. The Fisher test revealed that the correlation coefficient for attachment to the Dutch culture was significantly higher than that for attachment to the Turkish culture $(z$ score $=1.93, p=0.027$ ).

The results of the multivariate regression analyses are shown in Table 5. Self-management was associated negatively with older age $(\beta=-0.09, p=0.016)$ and multimorbidity $(\beta=-0.18, p<0.001)$, and positively with attachment to the Turkish $(\beta=0.15, p<0.001)$ and Dutch $(\beta=0.20, p<0.001)$ cultures.

\section{Discussion}

The results of this study demonstrate the importance of attachment to both the Turkish and Dutch cultures for the self-management abilities of older Turkish immigrants in the Netherlands. Slightly stronger relationships were found between self-management and attachment to the Dutch culture than attachment to the Turkish culture. Cultural values may be conveyed through older people's self-management abilities. In the Netherlands (as in other Western countries), engagement in selfmanagement activities and the strengthening of selfmanagement abilities have long been employed as effective preventive tools among chronically ill (and frail) older people [62]. Dutch society has changed from a demographically young welfare state to an ageing society with increasing individual responsibility [63]. Research has shown that Arabic- and Turkish-speaking communities initiate participation in self-management activities less often than do native speakers [64]. Muslim people are known to respond to illness and death with patience, meditation, and prayer, and may therefore turn more often to spiritual or religious coping strategies instead of working on self-management abilities [65]. Therefore, we hypothesise that Turkish migrants who follow the integration and assimilation acculturation strategies (both characterised by attachment to the Dutch culture) are better self-managers, not only because the skills needed to integrate contribute to self-management, but also

Table 3 Differences in self-management and attachment to the Dutch and Turkish cultures across older Turkish sub-groups ( $n=$ 680)

\begin{tabular}{|c|c|c|c|c|c|c|c|c|c|c|c|c|c|c|c|c|}
\hline & \multicolumn{4}{|c|}{ Gender } & \multicolumn{4}{|c|}{ Educational level } & \multicolumn{4}{|c|}{ Marital status } & \multicolumn{4}{|c|}{ Multimorbidity } \\
\hline & Male & Female & $t$ & p & High & Low & $t$ & p & Single & Married & $t$ & $p$ & Yes & No & $t$ & $p$ \\
\hline Self-management & $\begin{array}{l}2.57 \\
(0.61)\end{array}$ & $\begin{array}{l}2.45 \\
(0.64)\end{array}$ & -2.383 & 0.017 & $\begin{array}{l}2.64 \\
(0.59)\end{array}$ & $\begin{array}{l}2.48 \\
(0.63)\end{array}$ & -2.537 & 0.011 & $\begin{array}{l}2.43 \\
(0.65)\end{array}$ & $\begin{array}{l}2.55 \\
(0.61)\end{array}$ & -2.170 & 0.030 & $\begin{array}{l}2.42 \\
(0.62)\end{array}$ & $\begin{array}{l}2.74 \\
(0.59)\end{array}$ & -5.972 & $\begin{array}{l}< \\
0.001\end{array}$ \\
\hline $\begin{array}{l}\text { Attachment to the } \\
\text { Dutch culture }\end{array}$ & $\begin{array}{l}3.34 \\
(0.72)\end{array}$ & $\begin{array}{l}3.03 \\
(0.80)\end{array}$ & -5.214 & $\begin{array}{l}< \\
0.001\end{array}$ & $\begin{array}{l}3.49 \\
(0.78)\end{array}$ & $\begin{array}{l}3.11 \\
(0.75)\end{array}$ & -5.048 & $\begin{array}{l}< \\
0.001\end{array}$ & $\begin{array}{l}3.00 \\
(0.86)\end{array}$ & $\begin{array}{l}3.27 \\
(0.72)\end{array}$ & -3.660 & $\begin{array}{l}< \\
0.001\end{array}$ & $\begin{array}{l}3.12 \\
(0.78)\end{array}$ & $\begin{array}{l}3.37 \\
(0.74)\end{array}$ & -3.728 & $\begin{array}{l}< \\
0.001\end{array}$ \\
\hline $\begin{array}{l}\text { Attachment to the } \\
\text { Turkish culture }\end{array}$ & $\begin{array}{l}3.87 \\
(0.70)\end{array}$ & $\begin{array}{l}3.97 \\
(0.68)\end{array}$ & 1.832 & 0.067 & $\begin{array}{l}3.88 \\
(0.72)\end{array}$ & $\begin{array}{l}3.94 \\
(0.67)\end{array}$ & 0.965 & 0.335 & $\begin{array}{l}3.90 \\
(0.72)\end{array}$ & $\begin{array}{l}3.93 \\
(0.68)\end{array}$ & -0.466 & 0.641 & $\begin{array}{l}3.91 \\
(0.72)\end{array}$ & $\begin{array}{l}3.95 \\
(0.62)\end{array}$ & -0.713 & 0.476 \\
\hline
\end{tabular}

Values are presented as the mean (standard deviation). Results are based on two-sided tests 
Table 4 Associations between background characteristics, attachment to the Dutch and Turkish cultures, and self-management abilities $(n=680)$

\begin{tabular}{|c|c|c|c|c|c|c|c|}
\hline Characteristic & 1 & 2 & 3 & 4 & 5 & 6 & 7 \\
\hline \multicolumn{8}{|l|}{ 1. Sex (female) } \\
\hline 2. Age (years) & -0.05 & & & & & & \\
\hline 3. Marital status (single/widowed) & $0.41^{* * *}$ & $0.14^{* * *}$ & & & & & \\
\hline 4. Education (low) & $0.25^{* * *}$ & 0.05 & $0.12^{* *}$ & & & & \\
\hline 5. Multimorbidity & $0.21^{* * *}$ & 0.06 & $0.12^{* *}$ & $0.21^{* * *}$ & & & \\
\hline 6. Attachment to the Turkish culture & 0.07 & $0.08^{*}$ & -0.02 & 0.04 & -0.03 & & \\
\hline 7. Attachment to the Dutch culture & $-0.20^{* * *}$ & -0.07 & $-0.15^{* * *}$ & $-0.20^{* * *}$ & $-0.15^{* * *}$ & $0.09^{*}$ & \\
\hline 8. Self-management abilities & $-0.10^{*}$ & $-0.10^{* *}$ & $-0.09^{*}$ & $-0.10^{* *}$ & $-0.32^{* * *}$ & $0.16^{* * *}$ & $0.26^{* * *}$ \\
\hline
\end{tabular}

because they fit better in the Dutch culture, in which self-management is embedded more strongly.

Less attachment to Dutch culture was observed among women, single respondents, less-educated individuals, and those with multimorbidity. Men, more-educated respondents, married individuals, and those without multimorbidity used the integration acculturation strategy more often, whereas women, less-educated respondents, and single individuals used the separation strategy more often. Women, single individuals, less-educated respondents, and those with multimorbidity reported poorer self-management abilities. Research among older and chronically ill Dutch people (e.g. $[14,15,66]$ has shown that single and less-educated individuals are worse selfmanagers than are those who are married and more educated. In contrast to the finding that older Turkish women are worse self-managers than their male counterparts, older Dutch women are generally better selfmanagers than older Dutch men [13, 66]. Older Turkish women may have fewer opportunities to engage in selfmanagement behaviours and have to rely more on relatives and the government. For example, Staring et al. [67] showed that Turkish women living in the

Table 5 Results of multivariate regression analyses investigating relationships between background characteristics, attachment to the Dutch and Turkish cultures, and self-management of older Turkish immigrants in Rotterdam, the Netherlands

\begin{tabular}{lll}
\hline Characteristic & \multicolumn{2}{l}{ Self-management } \\
\cline { 2 - 3 } & $\beta$ & $p$ \\
\hline Sex (female) & -0.02 & 0.635 \\
Age (years) & -0.09 & 0.016 \\
Marital status (single/widowed) & -0.01 & 0.871 \\
Education (low) & -0.02 & 0.606 \\
Multimorbidity & -0.18 & $<0.001$ \\
Attachment to the Dutch culture & 0.20 & $<0.001$ \\
Attachment to the Turkish culture & 0.14 & $<0.001$ \\
\hline
\end{tabular}

Netherlands experience strict social control, which limits their ability to seek out contacts outside the Turkish community. The importance of attachment to the Dutch culture (using the integration or assimilation acculturation strategy) for people's self-management abilities observed in this study may explain why Turkish women were poorer self-managers than were Turkish men. In multivariate analyses that took attachment to the Dutch and Turkish cultures into account, older age and multimorbidity were the only background characteristics that remained associated (negatively) with Turkish immigrants' self-management abilities. Van Houtum et al. [68] clearly showed that deteriorating health resulting from chronic illness (es) led to increased self-management support needs over time. Health care for people with (multiple) chronic diseases often focuses only on physical health and clinical outcomes (e.g. 14, 15); older Turkish immigrants with multimorbidity may benefit more from health care supporting their broader selfmanagement abilities.

The limitations of this study should be taken into account when interpreting our findings. First, although the response rate of $32 \%$ seems low, it is similar to those achieved in other surveys of the same population [69]. We first invited respondents to fill in the questionnaire via mail, and then made a minimum of two personal contact attempts at respondents' homes. Previous research, however, has indicated that a minimum of six contact attempts is necessary to achieve an optimal response [5]; this approach was not feasible for the current study. Second, because of the study's cross-sectional design, we were unable to draw causal conclusions. Longitudinal data are needed to investigate the relationships between acculturation and self-management abilities over time. For example, although we found that multimorbidity was related negatively to the self-management abilities of older Turkish immigrants, this relationship is expected to be dynamic, as poor self-managers probably have a greater chance of becoming chronically ill. Third, the current study was limited to elderly Turkish 
residents of Rotterdam. A similar study conducted among Moroccans, the second largest migrant group in Rotterdam, would be of interest. Given that acculturation is not the responsibility of migrants solely but rather a result of a mutual dynamic interaction between migrants and the host country a better understanding of the acculturation strategies among various migrants within a country will help identify areas for improvement. In addition, as acculturation strategies and selfmanagement abilities are expected to vary across cultures and countries, comparative studies should be conducted among (im) migrant elders in other countries. Furthermore, we subjected the home and host culture scales to a median split to obtain the four acculturation strategies, following previous research [36, 58-60]. We did not use norm scores to determine the actual acculturation strategy used by each individual. We are therefore not sure whether the acculturation strategy data truly reflect relevant differences in these strategies between groups. Further research is needed to develop norm scores. Fourth, we did not include number of years in the host country. We do know that Turkish older people in the Netherlands are mainly first generation migrants (they were born in Turkey). Most of the men moved to the Netherlands just before 1973 and their families often joined them a couple of years later. This means that most of the Turkish older people live in the Netherlands for over 40 years [70]. Finally, we included four acculturation strategies only. Other theories such as social adaption [71, 72] (the adjustment of individual and group behaviour to conform with the prevailing system of norms and values in a given society, class, or social group) may be interesting to include in future research as well.

From the results of this study, we conclude that especially attachment to the Dutch culture matters for the self-management abilities of older Turkish immigrants in the Netherlands. Given the high prevalence of chronic diseases in this population, investment in their self-management abilities is expected to be beneficial. Special attention is needed for women, single individuals, lesseducated people, and those with multimorbidity. Interventions aiming to better integrate these groups into Dutch society are also expected to be beneficial for their self-management abilities.

\footnotetext{
Abbreviations

CCMO: Central Committee on Research Involving Human Subjects; DPAS: Dutch Psychological Acculturation Subscale; SMAS-S: Self-Management Ability Scale; T-PAS: Turkish Psychological Acculturation Subscale
}

\section{Authors' contributions}

JMC and APN contributed to the design of the study, performed the statistical data analyses, interpreted the findings, and drafted and refined the manuscript. All authors read and approved the final manuscript.

\section{Funding}

This study was supported by a grant provided by the Erasmus University of Rotterdam.

\section{Availability of data and materials}

The datasets analysed during the current study are available from the corresponding author on reasonable request.

\section{Ethics approval and consent to participate}

According to the CCMO, the current study did not fall within the scope of the Medical Research Involving Human Subjects Act and therefore did not have to undergo prior review by an accredited Medical Research and Ethics Committee or the CCMO. All respondents were informed about the aims of the study and its anonymous and voluntary nature, before giving their consent to participate. By filling in the questionnaires and sending it back to us though mail or agreeing to be interviewed face-to-face consent was implied.

\section{Consent for publication}

Not applicable.

\section{Competing interests}

The authors declare that they have no competing interests.

Received: 23 November 2018 Accepted: 11 August 2019

Published online: 05 September 2019

\section{References}

1. Korownyk, et al. Competing demands and opportunities in primary care. Can Fam Physician. 2017;63(9):664-8.

2. American Geriatrics Society (AGS) Expert Panel on Person-Centered Care Person-centered care: a definition and essential elements. J Am Geriatr Soc. 2016;64:15-8.

3. Foets M, Choté A, Hoefman R, Hofmeester E, Koopmans G, Lötters F. De toekomst van de thuiszorg voor hulpbehoevende allochtone ouderen [The future of homecare for immigrant older people with care needs]. Rotterdam: iBMG/STOOM; 2009.

4. Dijkshoorn H, Uitenbroek DG, Middelkoop BJC. Prevalentie van diabetes mellitus en hart-en vaatziekten onder Turkse, Marokkaanse en autochtone Nederlanders. [prevalence of diabetes mellitus and cardiovascular disease among immigrants from Turkey and Morocco and the indigenous Dutch population]. Ned Tijdschr Geneeskd. 2003;147:1362-6.

5. Schellingerhout R. Gezondheid en welzijn van allochtone ouderen [Health and well-being of ethnic minority elderly]. The Hague: Sociaal en Cultureel Planbureau; 2004

6. Van der Wurff FB, Beekman ATF, Dijkshoorn H, Spijker JA, Smits CHM, Stek ML, Verhoeff A. Prevalence and risk-factors for depression in elderly Turkish and Moroccan migrants in the Netherlands. J Affect Disord. 2004;83:33-41.

7. Poort EC, Spijker JA, Dijkshoorn H, Verhoeff A. Amsterdamse Gezondheidsmonitor 1999-2000. Turkse en Marokkaanse ouderen in Amsterdam. Gezondheid, zelfredzaamheid en zorggebruik [Amsterdam Health Monitor 1999-2000. Turkish and Moroccan elderly in Amsterdam. Health, self-efficacy, and health care use]. Amsterdam: GG \& GD Amsterdam; 2001

8. Solé-Auró A, Crimmins EM. Health of immigrants in European countries. Int Migr Rev. 2008;42(4):861-76.

9. Solé-Auró A, Guillén M, Crimmins EM. Health care usage among immigrants and native-born elderly populations in eleven European countries: results from SHARE. Eur J Health Econ. 2012;13(6):741-54.

10. World Health Organization, U.S. National Institute on Aging. Global health and ageing. 2011. http://www.who.int/ageing/publications/global_health/ en/. Accessed 28 June 2017

11. Lorig KR, Holman H. Self-management education: history, definition, outcomes, and mechanisms. Ann Behav Med. 2003:26:1-7.

12. Cramm JM, Hartgerink JM, de Vreede PL, Bakker TJ, Steyerberg EW, Mackenbach JP, Nieboer AP. The relationship between older adults' selfmanagement abilities, well-being and depression. Eur J Ageing. 2012;9:353-60.

13. Cramm JM, Hartgerink JM, Bakker TJ, Steyerberg EW, Mackenbach JP, Nieboer AP. Understanding older patients' self-management abilities: functional loss, self-management, and well-being. Qual Life Res. 2013;22(1): 85-92. 
14. Cramm JM, Nieboer AP. Chronically ill patients' self-management abilities to maintain overall well-being: what is needed to take the next step in the primary care setting? BMC Fam Pract. 2015;16:123.

15. Cramm JM, Nieboer AP. Disease management: the need for a focus on broader self-management abilities and quality of life. Popul Health Manag. 2015;18(4):246-55.

16. Cramm JM, Nieboer AP. The importance of health behaviours and especially broader self-management abilities for older Turkish immigrants. Eur J Pub Health. 2018:cky174. https://doi.org/10.1093/eurpub/cky174.

17. Kamperman AM, Komproe $\mathrm{H}$, de Jong JT. Migrant mental health: a model for indicators of mental health and health care consumption. Health Psychol. 2007;26:96-104.

18. Knipscheer JW, Kleber RJ. The relative contribution of posttraumatic and acculturative stress to subjective mental health among Bosnian refugees. J Clin Psychol. 2006;62:339-53.

19. Knipscheer JW, Kleber RJ. Acculturation and mental health among Ghanaians in the Netherlands. Int J Soc Psychiatry. 2007;53:369-83.

20. Wiking $E$, Johansson SE, Sundquist J. Ethnicity, acculturation, and self reported health. A population based study among immigrants from Poland, Turkey, and Iran in Sweden. J Epidemiol Community Health. 2004;58:574-82.

21. Gerritsen AA, Bramsen I, Deville W, van Willigen LH, Hovens JE, van der Ploeg HM. Health and health care utilisation among asylum seekers and refugees in the Netherlands: design of a study. BMC Public Health. 2004;4:7.

22. Landrine $\mathrm{H}$, Klonoff EA. Culture change and ethnic-minority health behavior: an operant theory of acculturation. J Behav Med. 2004;27:527-55.

23. Kabir Z, Clarke V, Keogan S, Currie LM, Zatonski W, Clancy L. Smoking characteristics of polish immigrants in Dublin. BMC Public Health. 2008;8:428

24. Hosper K, Klazinga NS, Stronks K. Acculturation does not necessarily lead to increased physical activity during leisure time: a cross-sectional study among Turkish young people in the Netherlands. BMC Public Health. 2007;7:230.

25. Egan M, Tannahill C, Petticrew M, Thomas S. Psychosocial risk factors in home and community settings and their associations with population health and health inequalities: a systematic meta-review. BMC Public Health. 2008:8:239.

26. Gordon MM. Human nature, class, and ethnicity. New York: Oxford University Press; 1978.

27. Berry JW, Poortinga YP, Segall MH, Dasen PR. Cross-cultural psychology: research and applications. Cambridge, UK: Cambridge University Press; 1992.

28. Buriel R. Acculturation, respect for cultural differences, and biculturalism among three generations of Mexican American and euro-American school children. J Genet Psychol. 1993;154:531-43.

29. Berry JW. Acculturation as varieties of adaptation. In: Padilla AM, editor. Acculturation: theory, models, and some new findings. Boulder, CO: Westview; 1980. p. 9-24.

30. LaFromboise T, Coleman HLK, Gerton J. Psychological impact of biculturalism: evidence and theory. Psychol Bull. 1993;114:395-412.

31. Padilla AM. The role of cultural awareness and ethnic loyalty in acculturation. In: Padilla AM, editor. Acculturation: theory, models and some new findings. Boulder: Westview; 1980. p. 47-84.

32. Berry JW. Immigration, acculturation, and adaptation. Appl Psychol Int Rev. 1997:46:5-34.

33. Berry JW, Kim U, Power S, Young M, Bujaki M. Acculturation attitudes in plural societies. Appl Psychol Int Rev. 1989;38:185-206.

34. Berry JW, Kim U, Boski P. Psychological acculturation of immigrants. In: Kim YY, Gudykunst WB, editors. Cross-cultural adaptation: current approaches. Newbury Park, CA: Sage Publications; 1988.

35. Berry JW. Acculturation and health: theory and research. In: Kazarian SS, Evans DR, editors. Cultural clinical psychology: theory, research, and practice. New York: Oxford University Press; 1998. p. 39-57.

36. Eyou ML, Adair V, Dixon R. Cultural identity and psychological adjustment of adolescent Chinese immigrants in New Zealand. J Adolesc. 2000;23:531-43.

37. Jasinskaja Lahti I, Liebkind K. Predictors of the actual degree of acculturation of Russian-speaking immigrant adolescents in Finland. Int J Intercult Relat. 2000;24:503-18

38. Nguyen $\mathrm{HH}$, von Eye A. The acculturation scale for Vietnamese adolescents (ASVA): a bidimensional perspective. Int J Behav Dev. 2002;26:202-13.

39. Phinney JS, Flores J. "Unpackaging" acculturation: aspects of acculturation as predictors of traditional sex role attitudes. J Cross-Cult Psychol. 2002;33(3): 320-31.
40. Nguyen HH, Messe LA, Stollak GE. Toward a more complex understanding of acculturation and adjustment: cultural involvements and psychosocial functioning in Vietnamese youth. J Cross-Cult Psychol. 1999;30:5-31.

41. Ryder $A G$, Alden LE, Paulhus DL. Is acculturation unidimensional or bidimensional? A head-to head comparison in the prediction of personality, self-identity, and adjustment. J Pers Soc Psychol. 2000;79:49-65.

42. Berry JW. Integration: a psychological and cultural perspective. The meaning of integration. Tallinn: Estonian Integration Found. 2008:23-32.

43. Berry JW. A critique of critical acculturation. Int J Intercult Relat. 2009;33:361-71.

44. Berry JW. Acculturation. In: Grusec J, Hastings P, editors. Handbook of socialisation theory and research. New York: Guilford; 2007. p. 343-558.

45. Chirkov V. Critical psychology of acculturation: what do we study and how do we study it, when we investigate acculturation? Int J Intercult Relat. 2009;33:94-105.

46. Chirkov V. Summary of the criticism and of the potential ways to improve acculturation psychology. Int J Intercult Relat. 2009;33:177-80.

47. Berry JW, Phinney JS, Sam DL, Vedder P, editors. Immigrant youth in cultural transition: acculturation, identity and adaptation across nations. Mawah: Lawrence Erlbaum Associates; 2006.

48. LaFromboise T, Rowe W. Skills training for bicultural competence: rationale and application. J Couns Psychol. 1983;30(4):589-95.

49. Chirkov V. Introduction to the special issue on critical acculturation psychology. Int J Intercult Relat. 2009;3:87-93.

50. Berry J. Conceptual approaches to acculturation. In: Chun KM, Organista PB, Marin $\mathrm{G}$, editors. Acculturation: advances in theory, measurement and applied research. Washington DC: American Psychological Association; 2003. p. 17-37

51. Xu Y, Pan W, Liu H. The role of acculturation in diabetes self-management among Chinese Americans with type 2 diabetes. Diabetes Res Clin Pract. 2011:93:363-70.

52. Gomez SL, Kelsey JL, Glaser SL, Lee MM, Sidney S. Immigration and acculturation in relation to health and health-related risk factors among specific Asian subgroups in a health maintenance organization. Am J Public Health. 2004;94(11):1977-84.

53. Tropp LR, Erkut S, Coll CG, Alarcon O, Garcia HAV. Psychological acculturation: development of a new measure for Puerto Ricans on the U.S mainland. Educational \& Psychological Measurement. 1999;59:351-67.

54. Stevens GWJM, Pels TVM, Vollebergh WAM, Crijnen AAM. Patterns of psychological acculturation in adult and adolescent Moroccan immigrants living in the Netherlands. J Cross-Cult Psychol. 2004;35:689.

55. Birman D, Trickett EJ. Cultural transitions in first-generation immigrants: acculturation of soviet Jewish refugee adolescents and parents. J Cross-Cult Psychol. 2001;32:456-77.

56. Birman D, Trickett EJ, Vinokurov A. Acculturation and adaptation of soviet Jewish refugee adolescents: predictors of adjustment across life domains. Am J Community Psychol. 2002;30:585-607.

57. Rodriguez N, Myers HF, Morris JK, Cardoza D. Latino college student adjustment: does an increased presence offset minority-status and acculturative stresses? J Appl Soc Psychol. 2000;30:1523-50.

58. Farver JAM, Bhadha BR, Narang SK. Acculturation and psychological functioning in Asian Indian adolescents. Soc Dev. 2002;11:11-29.

59. Ward C, Kennedy A. Acculturation strategies, psychological adjustment, and sociocultural competence during cross-cultural transitions. Int J Intercult Relat. 1994;18:329-43.

60. Ward C, Rana-Deuba A. Acculturation and adaptation revisited. J Cross-Cult Psychol. 1999;30:422-42.

61. Cramm JM, Strating MMH, de Vreede PL, Steverink N, Nieboer AP. Development and validation of a short version of the self-management ability scale (SMAS). Health Qual Life Outcomes. 2012;10:9.

62. O'Connell S, MC Carthy VJC, Savage E. Frameworks for self-management support for chronic disease: a cross-country comparative document analysis. BMC Health Serv Res. 2018;18(1):583. https://doi.org/10.1186/s12913-018-33 87-0.

63. Smits $\mathrm{CHL}$, van den Beld HK, Aartsen MJ, Schroots JJ. Aging in the Netherlands: state of the art and science. Gerontologist. 2014;54(3):335-43. https://doi.org/10.1093/geront/gnt096.

64. Furler J, Walker C, Blackberry I, Dunning T, Sulaiman N, Dunbar J, Best J, Young D. The emotional context of self-management in chronic illness: a qualitative study of the role of health professional support in the selfmanagement of type 2 diabetes. BMC Health Serv Res. 2008:8:214. https:// doi.org/10.1186/1472-6963-8-214 
65. Rassool GH. The crescent and Islam: healing, nursing and the spiritual dimension. Some considerations towards an understanding of the Islamic perspectives on caring. J Adv Nurs. 2000;32(6):1476-84.

66. Cramm JM, Twisk J, Nieboer AP. Self-management abilities and frailty are important for healthy aging among community-dwelling older people; a cross-sectional study. BMC Geriatr. 2014;14:28.

67. Staring R, Geelhoed F, Aslanoglu G, Hiah J, Kox M. The social position of Turkish-Dutch citizens developments and risks of criminality and radicalization. The Hague: Boom Lemma; 2014.

68. van Houtum L, Rijken M, Heijmans M, Groenewegen P. Self-management support needs of patients with chronic illness: do needs for support differ according to the course of illness? Patient Educ Couns. 2013;93(3):626-32.

69. Schmeets H. Slecht bereikbare allochtonen, autochtone weigeraars [difficult to reach ethnic minorities, native refusers]. In: Schmeets $\mathrm{H}$, van der Bie $\mathrm{R}$, editors. Enquêteonderzoek onder allochtonen: problemen en oplossingen [survey research among ethnic minorities: problems and solutions]. Voorburg/Heerlen: Centraal Bureau voor de Statistiek; 2005. p. 81-8.

70. Jaco Dagevos. De leefsituatie van allochtone ouderen in Nederland. [The living situation of older migrants in the Netherlands]. Sociaal en Cultureel Planbureau Den Haag, december, 2001

71. Kahle LR, Homer PM. Physical attractiveness of the celebrity endorser: a social adaptation perspective. J Consum Res. 1985;11(March):954-61.

72. Kahle LR. Attitudes and social adaptation: a person- situation interaction approach. Oxford, U.K.: Pergamon Press; 1984. isbn:0-08-026074-8.

\section{Publisher's Note}

Springer Nature remains neutral with regard to jurisdictional claims in published maps and institutional affiliations.

Ready to submit your research? Choose BMC and benefit from:

- fast, convenient online submission

- thorough peer review by experienced researchers in your field

- rapid publication on acceptance

- support for research data, including large and complex data types

- gold Open Access which fosters wider collaboration and increased citations

- maximum visibility for your research: over $100 \mathrm{M}$ website views per year

At BMC, research is always in progress.

Learn more biomedcentral.com/submissions 